\title{
IMPACT OF LEADERSHIP STYLES ON EMPLOYEE PERROMANCE: A REVIEW OF LITERATURE
}

\author{
Thaneswary Raveendran \\ Department of Human Resource Management \\ University of Jaffna, Sri Lanka. \\ E-mail : rthanes67@gmail.com \\ Aruna Shantha Gamage \\ Department of Human Resource Management, \\ University of Sri Jayewardenepura, Sri Lanka \\ E-mail : arunasgamage@gmail.com
}

\begin{abstract}
The business researchers are interested in identifying what leadership styles result in positive outcomes in organizations. From the work of the researchers, many theories and approaches have been developed time to time. This paper provides a literature review of transformational and transactional leadership styles and its impact on employee performance. The review outlines the major leadership theories and provides a framework for understanding the body of knowledge. Transformational and transactional leadership theories are discussed in detail in order to provide a specific leadership theoretical framework for this study. Empirical findings related to the study variables are discussed based on the literature. The review of literature shows that the leaders are perceived effective when they use transformational and transactional leadership styles together. Further several studies identified that, compared to transactional leadership, transformational leadership has more impact on employee performance. However, there is a gap in the current literature examining the effects of transformational and transactional leadership styles on employee performance in the Sri Lankan context. The review results would bring a platform for the future researchers to concentrate on the applicability of the theory in various sectors in Sri Lanka.
\end{abstract}

Keywords: transformational leadership, transactional leadership and employee performance, 


\section{Introduction}

Although transformational and transactional leadership have been studied extensively, the magnitude of the relationship between these leadership styles and follower performance across criterion types and levels of analysis remains unclear. The changing trend of work organizations, including acknowledgment of the effective utilization of human assets, has put increased significance on leadership (Mullins, 2007). Bass (2008) contends that leadership behaviour plays the most basic part, and is a critical subject for study and research. It is a typical phenomenon that things tend to transform; one method for doing things is replaced by another method. An exceptionally effective approach or strategy may not be successful in some other circumstance or time. Because of this consistent change, old strategies, approaches, and systems are replaced by some new, further developed and workable ones. In this manner, it is necessary to investigate about which leadership style works best. The review begins with importance of leadership research, definition of leadership and levels of conceptualization of leadership. The empirical evidences are organized, summarized and sought for generalizability of the findings.

This research has the potential to clarify the precise ways in which transformational and transactional leadership impact performance and may increase the practical utility of these leadership theories. Moreover, by comparing the relative effects of transformational and transactional leadership on different types and levels of performance, we can learn more about how these two types of leadership may work together to facilitate both effective performance across types and levels.

\section{Objective}

The objective of our study is to review the reported empirical evidences regarding the relative impact of transformational and transactional leadership styles on followers' task, contextual, and creative performance. This review of literature is an effort to form a base for understanding what style of leadership has more impact on employee performance and to identify the research gap. Thus the study would give a platform for future researchers for investigating the phenomenon.

\section{The importance of leadership research}

Leadership research is vital on the grounds that it leads towards identifying new, more developed and successful approaches and in addition assessment of the current 
leadership approaches (Barbuto, 2005). Also, leadership research investigates and gives direction with regard to qualities of leaders, behaviour of leaders and approaches of leaders. Moreover, it helps to understand that there is no perfect leadership behaviour or style which can be successful in every situation. In addition, each and every organization is unique to some degree in relation to another and has distinctive culture, condition and systems. Therefore, it is necessary to carry out a specific leadership research to determine the best leadership practice for a particular organization (Avolio, Walumbwa and Weber, 2009).

\section{Meaning of leadership}

With the increased complexity and change in operations globally, leadership has been a topic of debate, but no common definition has been agreed upon. According to Jong and Hartog (2007), leadership can be defined as a process of influencing people to get the desired outcomes. According to Cole (2005), Leadership is a dynamic process whereby one person influences others to contribute voluntarily to the attainment of the goals and objectives. Aspiration of values of the group that is representing the essence of leadership is to help a group or an organization to attain sustainable development and growth. Andersen (2016) stated that leaders are the ones who stimulate, motivate, and recognize their employees in order to get work done and achieve the desired results. Leadership styles adopted by leaders motivate and stimulate the employees for positive behaviours.

\section{Evolution of leadership approaches}

In leadership, many theories and approaches have been developed time to time. In this manner, there are four approaches to studying leadership. The first approach was the trait approach that emphasizes the personal qualities of leader. The second approach was leaders' leadership style behaviour approach which is concerned with identifying the kind of leader behaviour that enhances the effectiveness of subordinates. The third one was contingency approach which concerns the impact of situational factors upon leaders and followers. Finally, there is the new leadership approach which emphasizes the leadership vision and charisma. Each of these is described in more detail below.

\subsection{The traitapproach}

In the early history of leadership, researches focused on determining special traits or qualities which differentiate a leader from a non-leader. On the basis of this approach, 
individual characteristics are considered to determine leadership. This approach is based on the assumption that leaders could be identified by specific traits or characteristics. The aim of the trait approach was to identify the personal attributes of leaders which differentiated them from non-leaders.

\subsection{The behavioural approach}

The behaviour approach concentrates on what leaders actually do on the job. This approach focuses on the style or the behaviour of the leader rather than on his/her traits or qualities. From a series of studies which has been conducted at Ohio State University, it was concluded that major dimensions of leaders' behaviour involved two factors: consideration and initiating structure. Consideration refers to the extent to which the leader shows concern for followers.

A number of problems have been identified in the behavioural approach. Firstly, inconsistent finding, that is, the magnitude and direction of correlation between consideration and initiating styles and various outcome measures were highly variable. Also, some correlations failed to reach statistical significance (Korman, 1966). Secondly, behavioural approach studies failed to include situational variables in their research, that is, including variables which moderate the relationship between leader behaviour and various outcomes (Korman, 1966).

\subsection{The contingencyapproach}

The contingency approach focuses upon the impact of the situation in determining the leader's style. Fiedler (1967) argued that leadership performance depends on both the organization and the leader. He suggested that situational variables have a moderate effect on the relationship between leadership style and effectiveness. Fiedler (1967) stated that leadership performance depends much on the organization as it depends upon the leader's own attributes. The contingency approach emphasizes the importance of contextual factors, such as the leader's authority and discretion. It suggests that the effectiveness of leader behaviour is dependent upon the situation.

\subsection{Thenewleadership approach}

By 1980 researchers realized that the old leadership approaches didn't have practical implications. Most of the older approaches have many shortcomings, such as inconsistent findings, measurement problems, and the problem of causality. These 
problems led to general doubt about leadership theory and research and stimulated fresh thinking which led to a new approach. More important theory is full-range of leadership theory (FRL) which includes transformational leadership theory, transactional leadership theory and lassiez-faire leadership theory (Northouse, 2007; Bass, 2008). Under this 'FRL' theory in particular, transformational and transactional leadership are discussed in more detail in order to provide a specific leadership theoretical framework for the present study.

\section{Transformational and Transactional leadership}

Leadership theories indicate that leadership behaviors can be categorized into two main styles: transformational leadership and transactional leadership (Bass \& Avolio, 1997; 2000). Transformational and transactional leadership have gained academic attention over the last few decades as a new paradigm for understanding leadership. The present study attempts to explore transformational and transactional styles of leadership and its impact on the performance of employees in the public sector organizations in the Northern Province of Sri Lanka. Therefore, both of these styles are discussed in detail.

\subsection{Transformational leadership}

Transformational Leadership Theory is interested in the extent to which a leader influences followers. Followers go after a leader because of trust, honesty, and other qualities and the stronger these are, the greater loyalty they have for the leader. The leader transforms the followers because of his or her qualities. While the leader may have democratic motives in mind, he/she can assume a transaction leadership style at the same time, directing the followers to do things. Transformational leadership is a value driven type of leadership that speaks to enduring human capacity for excellence and pride accomplishment. For transformational leadership to work effectively, trust is important so as to induce voluntary commitment and performance.

Burns (1978) introduced the concept of trasformational leadership. He identified that transformational leaders modify the beliefs and attitudes of the employees by inspiring them. They provide their employees a vision and motivate them in achieving particular goals. According to Rouche, Baker, and Rose (1989), transformational leaders help their followers to accomplish the organizational goals and mission by working with them and through them. The components of transformational leadership are known as Four I's and includes idealized influence (baviour and 
attributes), Inspirational motivation, Intellectual stimulation and Individualized consideration.

Inspirational Motivation of transformational leadership is the articulation and representation of a vision by the leader. Consequently, by viewing the future with a positive attitude, followers are motivated. Idealized Influence (attributes) refers to the attribution of charisma to the leader. Because of the leaders' positive attributes (e. g. perceived power, focusing on higher-order ideals and values), followers built close emotional ties to the leader. Trust and confidence is likely to be built in followers. Idealized Influence (behavior) emphasizes a collective sense of mission and values, as well as acting upon these values. Idealized influence and inspirational motivation are often conceptualized as charismatic leadership dimension in a lot of research in transformational leadership. Intellectual Stimulation includes challenging the assumptions of followers' beliefs, their analysis of problems they face and solutions they generate. Individualized Consideration is defined by considering individual needs of followers and developing their individual strengths. Transformational leadership is more like visionary leadership, in which leaders motivate their employees to exceed certain expectations (Hater \& Bass, 1988).

\subsection{Transactionalleadership}

Transactional leadership refers to behaviors in the context of scripted, rational exchanges between leaders and followers, typically with a view to the accomplishment of a set of goals. Transactional leadership theory seeks to explain and describe the behaviors in and around these interactions or transactions. Burns (1978) points out that transformational leadership should empower leaders not only to take the initiative to engage with followers but also engage creatively in a manner that recognizes and responds to the important wants of potential followers.

Transactional leadership is an exchange pr cess. It is a matter of contingent reinforcement of employees based on performance. It motivates subordinates by appealing to their personal desires, based on instrumental economic transactions. Transactional leaders generally use organizational bureaucracy, policy, power, and authority to maintain control; this style of leadership is occasionally referred to as authoritative (Bennet, 2009). Bass (1985) and his associates (Avolio, Bass \& Jung, 1999; Bass \& Avolio, 1990; Hater \& Bass, 1988) also hypothesized three behavior dimensions that underlie transactional leadership: Contingency reward, Management by exception- active and Management by exception-passive. 
Contingent reward is considered a constructive form of behaviour (Obiwuru, Okwu, Akpa, and Nwankwere, 2011). It means the extent to which leaders set goals, make rewards (material or psychological) on performance, obtain necessary resources, and provide rewards when performance goals are met. Management by exception - active is considered a corrective form of behaviour (Obiwuru et al., 2011). It can take the form of active management by exception where the leader specifies standards for compliance and what is considered ineffective performance, the leader then monitors the performance of followers and takes corrective action. Management by exceptionpassive refers to the extent to which leaders may not be aware of problems until informed by others and generally fail to intervene until serious problems occur. The leader intervenes only after errors have been detected or if standards have not been met. In this form corrective actions are taken once problems have occurred (Birasnav, 2014).

\section{Employee performance}

Employee performance is said to be a multidimensional construct (Befort \& Hattrup, 2003). This has induced both practitioners and researchers to identify the dimensions of employee performance with the aim of managing employee performance in organizations. A widely accepted method of conceptualization of employee performance is the role-based model of performance (Welbourne, Johnson, \& Erez, 1998). Role of employees on the job is central to the effectiveness of the organization and measurement of employee performance should consider it. It is said that the employees' behavior on the job determines the level of performance of them. Katz and Kahn (1978) first divided job performance into task performance and contextual performance. Task performance can be defined as the effectiveness of activities contributing to organization operation. Contextual performance refers to the extent to which employees contribute to the development of organizations in promoting organizational culture. Numerous studies have examined the relationship between transformational and transactional leadership and employee performance.

\section{Empirical evidence}

\subsection{Effect of transformational leadership on employee performance}

The effect of transformational leadership on performance was proposed by Butler (1999) that a transformational leader encourages subordinates to have vision, mission and organization goals, encouraging and motivating to show maximum performance, 
stimulates subordinates to act critically and to solve problems in new ways and treat employees individually. As a consequence subordinates will reciprocate by showing maximum work. Similarly, Suharto (2005) suggests that more frequent transformational leadership behaviors implemented will bring significant positive effect to improve psychological empowerment quality of subordinates.

Elgelala and Noermijatib (2014) investigated the influences of transformational leaderships on employee motivation, job satisfaction and employees performance of the Economics and Business Faculty Employee at University of Muhammadiyah Malang. The research was conducted with all employees at Economics and Business Faculty, University of Muhammadiyah Malang. The finding of this study revealed that transformational leadership gives positive and significant effect on employee motivation and employees' job satisfaction, but no significant effect found on employee performance.

Andreani and Petrik (2016) showed that there is a positive and significant impact of transformational leadership on job satisfaction, a positive but insignificant impact of job satisfaction on employee performance, and a positive and significant impact of transformational leadership on employee performance. The same findings have been reported in several studies (Jiang, Lu, \& Le, 2016; Sparkling, Mollaoglu, \& Kirca, 2016; Andreani \& Petrik, 2016; Yammarino, \& Dubinsky, 1994; Spangler, \& Braiotta, 1990).

\subsection{Effect of transactional leadership on employee performance}

There is plenty of empirical evidence that transactional leadership affect on employee performance. In transactional leadership, there is exchange relationship between the leader and the subordinates where subordinates are expected to offer a performance to leader, in this case the form of transaction, leader offers rewards. Transaction process between leaders and subordinates directed to produce a satisfactory performance. It consistent with theory of Bass and Avolio (2003) which says that transactional leadership style affects on employee performance. Transactional leadership styles can affect positively or negatively on performance. It depends on employee assessment. Positive effect can occur when employees assess transactional leadership positively and a negative effect can occur if employee considers that transactional leadership styles cannot be trusted because they do not keep their promises, dishonest or not transparent. 
A study conducted by Howell \& Avolio (1993) confirms that contingent reward leadership has a negative impact on the followers' performance. Contingent reward is viewed as "an active and positive exchange between leaders and followers whereby followers are awarded for accomplishing agreed upon objective". If managers do not effectively follow-up on the contingent reward promises, thereby displaying behavioral inconsistency, they are viewed as ineffective leaders. Furthermore, Howell \& Avolio (1993) suggest that the level of contingent reward leadership is dependent on organizational context and settings. For example, an organization undergoing change might suffer from a transactional leadership style.

\section{Table 1 : Summary of empirical findings}

\begin{tabular}{|l|l|l|l|}
\hline \multicolumn{1}{|c|}{ Author } & \multicolumn{1}{|c|}{ variables studied } & \multicolumn{1}{c|}{ Sample \& Sector } & \multicolumn{1}{c|}{ Findings } \\
\hline $\begin{array}{l}\text { Ali, Jan, Ali } \\
\text { and Tariq } \\
\text { (2014) }\end{array}$ & $\begin{array}{l}\text { Impact of } \\
\text { transformational and } \\
\text { transactional } \\
\text { leadership on job } \\
\text { satisfaction, } \\
\text { organizational } \\
\text { commitment, } \\
\text { organizational } \\
\text { citizenship behavior, } \\
\text { employees' } \\
\text { perceived } \\
\text { performance and } \\
\text { turnover intention } \\
\text { including lecturers, } \\
\text { assistant professors, } \\
\text { associate professors } \\
\text { and professors in } \\
\text { public sector } \\
\text { universities in } \\
\text { Malakand division } \\
\text { of Pakistan }\end{array}$ & $\begin{array}{l}\text { Transformational } \\
\text { and transactional } \\
\text { leadership have } \\
\text { impact on perceived } \\
\text { performance while } \\
\text { transactional } \\
\text { leadership was a } \\
\text { stronger predictor of } \\
\text { perceived } \\
\text { performance than } \\
\text { transformational } \\
\text { leadership. }\end{array}$ \\
\hline $\begin{array}{l}\text { Baig, } \\
\text { Mohammed, } \\
\text { Soon and } \\
\text { Baig (2015) }\end{array}$ & $\begin{array}{l}\text { Examining the } \\
\text { relationship of } \\
\text { leadership styles and } \\
\text { perceived employee } \\
\text { performance and } \\
\text { further explores the } \\
\text { moderating effect of } \\
\text { individual culture } \\
\text { orientation }\end{array}$ & $\begin{array}{l}\text { Sample of 127 } \\
\text { subordinates in } \\
\text { banking sector of } \\
\text { Pakistan }\end{array}$ & $\begin{array}{l}\text { Transformational } \\
\text { and transactional } \\
\text { leadership have } \\
\text { positive associations } \\
\text { with perceived } \\
\text { employee } \\
\text { performance. In } \\
\text { addition, } \\
\text { transformational } \\
\text { leadership has } \\
\text { stronger and } \\
\text { positive associations } \\
\text { with perceived } \\
\text { employee } \\
\text { performance. }\end{array}$ \\
\hline
\end{tabular}




\begin{tabular}{|l|l|l|l|}
\hline $\begin{array}{l}\text { Cavazotte, } \\
\text { Moreno and } \\
\text { Bernardo } \\
(2013) .\end{array}$ & $\begin{array}{l}\text { Transformational } \\
\text { leadership and } \\
\text { subordinate formal } \\
\text { and contextual } \\
\text { performance among } \\
\text { Brazilian } \\
\text { employees. }\end{array}$ & $\begin{array}{l}\text { 107 managers from } \\
\text { a multinational } \\
\text { company that } \\
\text { operates in the } \\
\text { financial sector. }\end{array}$ & $\begin{array}{l}\text { Perceived } \\
\text { transformational } \\
\text { leadership is } \\
\text { associated with } \\
\text { higher levels of task } \\
\text { performance and } \\
\text { helping behaviors. }\end{array}$ \\
\hline $\begin{array}{l}\text { Chamika and } \\
\text { Gunasekara } \\
\text { (2016). }\end{array}$ & $\begin{array}{l}\text { Transformational } \\
\text { and transactional } \\
\text { leadership styles on } \\
\text { employee' } \\
\text { performance. }\end{array}$ & $\begin{array}{l}\text { 80 employees from } \\
\text { the banking sector in } \\
\text { Sri Lanka }\end{array}$ & $\begin{array}{l}\text { Transformational } \\
\text { leadership could } \\
\text { have larger effects } \\
\text { on employee } \\
\text { productivity and } \\
\text { quality of } \\
\text { performance. }\end{array}$ \\
\hline $\begin{array}{l}\text { Elgelala and } \\
\text { Noermijatib } \\
(2014)\end{array}$ & $\begin{array}{l}\text { Influence of } \\
\text { transformational } \\
\text { leaderships on } \\
\text { employee } \\
\text { motivation, job } \\
\text { satisfaction and } \\
\text { employees } \\
\text { performance }\end{array}$ & $\begin{array}{l}\text { All employees of } \\
\text { Economics and } \\
\text { Business Faculty at } \\
\text { University of } \\
\text { Muhammadiyah } \\
\text { Malang. }\end{array}$ & $\begin{array}{l}\text { Transformational } \\
\text { leadership have no } \\
\text { significant effect on } \\
\text { employee } \\
\text { performance. }\end{array}$ \\
$\begin{array}{l}\text { Transformational, } \\
\text { Transactional } \\
\text { Leadership Styles } \\
\text { and Job } \\
\text { Performance of } \\
\text { Academic Leaders } \\
\text { in higher learning } \\
\text { institution }\end{array}$ & $\begin{array}{l}\text { Influence of } \\
\text { transformational and } \\
\text { transactional } \\
\text { leadership styles on } \\
\text { employees' } \\
\text { knowledge sharing } \\
\text { practices, and the } \\
\text { impact of the latter } \\
\text { on job performance, } \\
\text { and then on firm } \\
\text { performance. }\end{array}$ & $\begin{array}{l}\text { 179 employees at } \\
\text { the higher council of } \\
\text { youth in Jordan }\end{array}$ & $\begin{array}{l}\text { Transformational } \\
\text { and transactional } \\
\text { leadership styles } \\
\text { have significant } \\
\text { impact on job } \\
\text { performance and } \\
\text { then on firm } \\
\text { performance. }\end{array}$ \\
\hline $\begin{array}{l}\text { Mahdinezhad } \\
\text { Suandi, Silong } \\
\text { and Omar } \\
\text { (2013) }\end{array}$ & & $\begin{array}{l}\text { Transactional } \\
\text { contingent rewards) } \\
\text { and transformational } \\
\text { styles of leadership } \\
\text { influence } \\
\text { performance of } \\
\text { academic leaders. }\end{array}$ \\
\hline
\end{tabular}




\begin{tabular}{|c|c|c|c|}
\hline $\begin{array}{l}\text { Paracha, } \\
\text { Qamar, Mirza, } \\
\text { Inam-ul- } \\
\text { Hassan, and } \\
\text { Waqas (2012) }\end{array}$ & $\begin{array}{l}\text { Impact of } \\
\text { transformational and } \\
\text { transactional } \\
\text { leadership style on } \\
\text { employee } \\
\text { performance }\end{array}$ & $\begin{array}{l}6 \text { schools in } \\
\text { Rawalpindi and } \\
\text { Islamabad in } \\
\text { Pakistan. }\end{array}$ & $\begin{array}{l}\text { Transactional and } \\
\text { transformational } \\
\text { leadership styles } \\
\text { significantly } \\
\text { positively associated } \\
\text { with employee } \\
\text { performance, }\end{array}$ \\
\hline Sundi (2013) & \begin{tabular}{|l} 
Effects of \\
Transformational \\
and Transactional \\
Leadership on \\
Employee \\
Performance
\end{tabular} & $\begin{array}{l}126 \text { respondents } \\
\text { from Konawe } \\
\text { Bureau staff at } \\
\text { Southeast Sulawesi } \\
\text { Province }\end{array}$ & $\begin{array}{l}\text { Transformational } \\
\text { leadership and } \\
\text { transactional } \\
\text { leadership have } \\
\text { positive effect on } \\
\text { performance. }\end{array}$ \\
\hline $\begin{array}{l}\text { Wang, Oh, } \\
\text { Courtright, } \\
\text { and Colbert } \\
\text { (2011) }\end{array}$ & $\begin{array}{l}\text { Transformational } \\
\text { Leadership and } \\
\text { Performance Across } \\
\text { Criteria and Levels: } \\
\text { A Meta-Analytic } \\
\text { Review of } 25 \text { Years } \\
\text { of Research }\end{array}$ & $\begin{array}{l}\text { Meta-analytic study } \\
\text { of } 117 \text { independent } \\
\text { samples over } 113 \\
\text { primary studies, }\end{array}$ & $\begin{array}{l}\text { Transformational } \\
\text { leadership was } \\
\text { positively related to } \\
\text { performance at the } \\
\text { team and } \\
\text { organization levels. } \\
\text { Transformational } \\
\text { leadership had an } \\
\text { augmentation effect } \\
\text { over transactional } \\
\text { leadership } \\
\text { (contingent reward) } \\
\text { in predicting } \\
\text { individual-level } \\
\text { contextual } \\
\text { performance and } \\
\text { team-level } \\
\text { performance. }\end{array}$ \\
\hline $\begin{array}{l}\text { Pradeep and } \\
\text { Prabhu (2011) }\end{array}$ & & & $\begin{array}{l}\text { Leadership is } \\
\text { positively linked } \\
\text { with employee } \\
\text { performance for } \\
\text { both } \\
\text { transformational } 1\end{array}$ \\
\hline
\end{tabular}




\begin{tabular}{|c|c|c|c|}
\hline & & & $\begin{array}{l}\text { eadership behaviors } \\
\text { and transactional } \\
\text { contingent reward } \\
\text { leadership } \\
\text { behaviors. }\end{array}$ \\
\hline $\begin{array}{l}\text { MacKenzie, } \\
\text { Podsakoff, and } \\
\text { Rich (2001) }\end{array}$ & $\begin{array}{l}\text { Impact of } \\
\text { transformational and } \\
\text { transactional leader } \\
\text { behaviors on the } \\
\text { sales performance } \\
\text { and organizational } \\
\text { citizenship } \\
\text { behaviors of } \\
\text { salespeople }\end{array}$ & $\begin{array}{l}477 \text { sales agents } \\
\text { working for a large } \\
\text { national insurance } \\
\text { company. }\end{array}$ & $\begin{array}{l}\text { Transformational } \\
\text { leadership } \\
\text { influences } \\
\text { salespeople to } \\
\text { perform "above and } \\
\text { beyond the call of } \\
\text { duty" but also that } \\
\text { transformational } \\
\text { leader behaviors } \\
\text { actually have } \\
\text { stronger direct and } \\
\text { indirect } \\
\text { relationships with } \\
\text { sales performance } \\
\text { and organizational } \\
\text { citizenship behavior } \\
\text { than transactional } \\
\text { leader behaviors. }\end{array}$ \\
\hline $\begin{array}{l}\text { Dvir, Eden, } \\
\text { Avolio, and } \\
\text { Shamir (2002) }\end{array}$ & $\begin{array}{l}\text { Impact of } \\
\text { transformational } \\
\text { leadership, enhanced } \\
\text { by training, on } \\
\text { follower } \\
\text { development and } \\
\text { performance }\end{array}$ & $\begin{array}{l}\text { The sample included } \\
54 \text { military leaders, } \\
\text { their } 90 \text { direct } \\
\text { followers, and } 724 \\
\text { indirect followers. }\end{array}$ & $\begin{array}{l}\text { The leaders in the } \\
\text { experimental group } \\
\text { who got } \\
\text { transformational } \\
\text { leadership training } \\
\text { had a more positive } \\
\text { impact on direct } \\
\text { followers' } \\
\text { development and on } \\
\text { indirect followers' } \\
\text { performance than } \\
\text { did the leaders in the } \\
\text { control group who } \\
\text { got electrical } \\
\text { training. }\end{array}$ \\
\hline
\end{tabular}




\begin{tabular}{|l|l|l|l|}
\hline McColl- & Relationship & Sample of 121 sales & Transformational \\
Kennedy and & between leadership & representatives of a & leadership has a \\
Anderson & style and & global & pharmaceutical firm \\
(2002) & subordinate & located in Australia & performance \\
& performance & & \\
\hline
\end{tabular}

Source : Summarized by the researcher from review of past researches

From the review of literature it is evident that leadership style can explain significant number of performance outcomes at individual level. In the reported studies in Table, except the study of Elgelala and Noermijatib (2014), all other studies found significant positive relationship between both transformational and transactional leadership styles and employee performance. The same findings also reported in Kehinde and Banjo (2014), Tsigu and Rao (2012) and Gimuguni, Nandutu and Magolo (2014). The majority of studies conducted on the relationship between transformational leadership and employee performance reported positive relationship between them (Deluga \& Souza, 2011; Howell, Neufeld \& Avolio, 2005; Geyery \& Steyrer, 1998 and Thamrin, 2012). Accordng to Paracha, Qamar, Mirza, Inam-ul-Hassan, and Waqas (2012) and Ali, Jan, Ali and Tariq (2014), transactional leadership was a stronger predictor of perceived performance than transformational leadership. However, Burns' (1978) view is that transformational leadership is more effective than transactional leadership. This strong effect of transformational leadership on employee performance was reported in several studies (Baig, Mohammed, Soon \& Baig, 2015; Wang, Oh, Courtright \& Colbert, 2011; and Chamika \& Gunasekara, 2016)

\section{Research gap}

There has been considerable empirical research (e.g., Basham, 2012; Bolden, Gosling, O’Brien, Peters, Ryan, \& Haslam, 2012; Herbst, \& Conradie, 2011; LópezDomínguez, Enache, Sallan, \& Simo, 2014; Sani \& Maharani, 2012; Vinger, 2009) on leadership in the higher education and other sectors in various countries. Specifically, there are adequate evidence of empirical studies on leadership and performance in schools, universities, military, insurance sector, banking sector and so on. However, these studies have varied widely in terms of context, purpose and methodology. There is evidence of few studies in the subject of leadership in Sri Lanka in few sectors; remarkably, studies on the impact of transformational and transactional leadership styles on various outcomes such as knowledge creation in Sri Lankan Software 
Industry (Athukorala, Perera, \& Meedeniya, 2016), employee' performance in banking industry (Chamika \& Gunasekara, 2016), Union and Organizational Commitment in public sector organizations in Sri Lanka (Dhammika, Ahmad, \& Sam, 2013), etc.

However, still there is need for studies in the subject of leadership in public sector organizations in Sri Lanka, where the people's cultural aspects like values, attitudes and behaviours differ noticeably. Furthermore, previous research has separately applied different types of leadership theories such as autocratic and democratic leadership, servant leadership, authentic leadership and, task and people oriented leadership theories to examine the variables of interest. Thus, there is a gap in the current literature examining the effects of transformational and transactional leadership styles on employee outcomes in Sri Lankan context.

Moreover, there are methodological problems with most existing studies. The majority of field studies have been cross-sectional in design, and the common-method bias often has been a problem when performance has been measured (Barling et al., 2002; Jermier and Kerr, 1997). The quality of performance measurement is critical to determining outcomes about whether leadership matters and not all studies have been well designed (Dionne et al., 2002). In several public sector organizations, employees do not have enough tasks to undertake resulting in idling without anything to do. This kind of situation severely affects the productivity of the individuals and organizations. The organization with a corporate strategy and plan automatically builds up commitment to justify its existence and know what its final destination is and how it could reach there. This kind of clearance increases the chances that an organization will be successful and success builds commitment as all the members in the organizations are assigned with specific tasks to be fulfilled by them. In addition, if the plan and the strategy are clear and well communicated, the employees would be more motivated, and remain focused and this situation leads to increase the performance of the individuals and organizations.

\section{Directions for future research}

The review of the literature portrays that different leadership paradigms could affect performance differently, depending on the context. Thus, when researching the leadership-performance relationship, the context needs to be taken into account and more paradigms need to be considered. Researchers who are interested in the field of 
leadership studies may investigate the impact of leadership on employee performance in the public sector in Sri Lanka where there are very few reported evidences. Further, employee performance could be improved through enhancing organizational commitment, organizational citizenship behaviour, employee empowerment and so on. Hence, researchers could investigate the mediating role of variables such as organizational commitment, organizational citizenship behaviour, employee empowerment, etc in the effect of leadership styles on employees' outcomes.

\section{Conclusion and implications}

Research findings have consistently highlighted the positive influence of transformational and transactional leadership on employee performance. To conclude, both transformational and transactional leadership styles govern employee perception towards their leaders, job performance and organizational productivity. There is plentiful literature to support that leaders are perceived effective when they use transformational and transactional leadership styles together. Further the review of literature reveled that, compared to transactional leadership, transformational leadership has more impact on employee performance. To confirm the effect of leadership on performance of employees in the Sri Lankan context, future researches should be directed towards the phenomenon.

No clear picture has emerged about the relationship between leadership and performance. Despite increased research into the leadership-performance relationship, many problems and gaps remain in existing studies. There is a lack of integration concerning the relationship between leadership and performance, a narrow set of variables has been used in previous studies, but the context and levels have been ignored. Therefore, there is a need for clarification.

\section{References}

Ali, N., Jan, S., Ali, A., \& Tariq, M. (2014). Transformational and transactional leadership as predictors of job satisfaction, commitment, perceived performance and turnover intention (empirical evidence from Malakand division, Pakistan). Life Science Journal, 11(5), 48-53. 
Andreani, F., \& Petrik, A. (2016). Employee Performance as the Impact of Transformational Leadership and Job Satisfaction in Pt Anugerah Baru Denpasar. Journal of Management and JMK, 18(1), 25-32. DOI: 10.9744/jmk.18.1.25-32

Avolio, B. J; Walumbwa, F. and Weber, T. J. (2009). "Leadership: Current Theories, Research, and Future Directions". Annual Review of Psychology, 60 (2), 441-462.

Avolio, B.J., Bass, B.M., \& Jung, D.I. (1999). Reexamining the components of transformational and transactional leadership using the Multifactor Leadership Questionnaire. Journal of Occupational and Organizational Psychology, 72, 441-462. http://dx.doi.org/10.1348/096317999166789

Baig, J., Mohammed, A.A.E., Soon, N.K., Baig, S. (2015). The Moderating Effect of Individual Culture Orientation on the Relationship between Leadership Styles with Perceived Employees Performance, European Journal of Scientific Research, 432-445

Barbuto, J.E. (2005). Motivation and Transactional, Charismatic, and Transformational Leadership: A Test of Antecedents. Journal of Leadership and Organisational Studies, 11(4), 26-40.

Barling, J., Loughlin, C. \& Kelloway, E.K. (2002). Development \& test a model linking safety-specific transformational leadership \& occupational safety. Journal of Applied Psychology, 87(3), 488-496.

Basham, LM 2012, Transformational and transactional leaders in higher education. SAM Advanced Management, Spring, 15-37.

Bass, B. M. (2008). Handbook of Leadership, Theory, Research, and Managerial Applications. (4th ed). NY: Free Press.

Bass, B.M. (1985). Leadership and performance beyond expectations. New York: Free Press.

Bass, B.M. (1997). Does the transactional-transformational leadership paradigm transcend organisational and national boundaries? American Psychologist, 52 (2), 30-139

Befort, N., \& Hattrup, K. (2003). Valuing task and contextual performance: Experience, job roles, and ratings of the importance of job behaviors. Applied HRM Research, 8(1), 17-32.

Bennett, T. M. (2009). A study of the management leadership style preferred by IT subordinates. Journal of Organizational Culture, Communications and Conflict, 13(2), 1-26. 
Birasnav, M. (2014). "Relationship between transformational leadership behaviors and manufacturing strategy", International Journal of Organizational Analysis , 22(2), 205-223.

Burns, J.M. (1978). Leadership. New York : Harper Torchbooks

Butler Jr, J. K., Cantrell, R. S., \& Flick, R. J. (1999). Transformation leadership behaviors, upward trust, and satisfaction in self-managed work teams. Organization Development Journal, 17(1), 13-16

Cavazotte, F., Moreno, V., \& Bernardo, J. (2013). Transformational leaders and work performance: The mediating roles of identification and self-efficacy. $B A R$ Brazilian Administration Review, 10(4), 490-512.

Chamika, M.W., \& Gunasekara, U.L.T.P. (2016). The Impact of Leadership Styles on Employee Performance. Proceedings of the Research Conference - 2016, Department of Accountancy, Faculty of Commerce and Management Studies, University of Kelaniya, Sri Lanka. Retrieved from :https://www.researchgate.net/publication/303688190_The_impact_of_tran sformational_and_transactional_leadership_styles_on_knowledge_creation _in_Sri_Lankan_software_industry [accessed Aug 7, 2017]

Cole, G.A. (2005). Personnel and Human Resource Management. London: ELST Publishers.

dan Cahyo, S. (2005). Pengaruh Budaya Organisasi, Kepemimpinan Dan Motivasi Terhadap Kinerja Sumber Daya Manusia Di Sekretariat DPRD Propinsi Jawa Tengah. JRBI, 1(1), 13-30.

Deluga, R. J., \& Souza, J. (2011). The effects of transformational and transactional leadership styles on the influencing behaviour of subordinate police officers. Journal of Occupational Psychology, 64(1), 49-55. http://dx.doi.org/10.1111 /j. 2044-8325.1991.tb00540.x

Dvir, T., Eden, D., Avolio, B. J., \& Shamir, B. (2002). Impact of transformational leadership on follower development and performance: A field experiment. Academy of management journal, 45(4), 735-744.

Elgelala, K.S.K., \& Noermijatib, (2014). The Influences of Transformational Leaderships on Employees Performance (A Study of the Economics and Business Faculty Employee at University of Muhammadiyah Malang). AsiaPacific Management and Business Application, 3 (1), 48-66 
Elgelala, K.S.K., \& Noermijatib, (2014). The Influences of Transformational Leaderships on Employees Performance (A Study of the Economics and Business Faculty Employee at University of Muhammadiyah Malang). AsiaPacific Management and Business Application, 3 (1), 48-66

Fiedler, F. E. (1967). A Theory of leadership effectiveness. New York: McGrawHill.

Geyery, A. L. J., \& Steyrer, J. M. (1998). Transformational leadership and objective performance in banks. Applied Psychology, 47(3), 397-420. http://dx.doi.org /10.1111/j. 1464-0597.1998.tb00035.x

Gimuguni, L., Nandutu, J., \& Magolo, A. (2014). Effect of leadership styles on performance of local governments in Uganda, A case of Mbale District.

Hater, J.J., Bass, B.M. (1988). Superiors' evaluations and subordinates' perceptions of transformational and transactional leadership. Journal of Applied Psychology, 73 (4) 695-702

Herbst, T.H.H., \& Conradie, P.D.P. (2011). Leadership effectiveness in higher education: managerial self perceptions versus perceptions of others. South African Journal of Psychology, 37 (1) 1-14.

Howell, J. M. \& Avolio, B. J. (1993), Transformational leadership, transactional leadership, locus of control, and support for innovation: Key predictors of consolidated business-unit performance. Journal of Applied Psychology, 78, 891-902.

Howell, J. M., Neufeld, D. J., \& Avolio, B. J. (2005). Examining the relationship of leadership and physical distance with business unit performance. The Leadership Quarterly, 16(2), 273-285. http://dx.doi.org/10.1016/j .leaqua.2005.01.004

Jermier, J.M. \& Kerr, S. (1997). Substitutes for leadership: Their meaning \& measurement. The Leadership Quarterly, 8(2), 95-101.

Jiang, W., Lu, Y. \& Le, Y. (2016). Trust and project success: A two fold perspective between owners and contractors. Journal of Management Engineering, 32, 04016022

Jong, J., Hartog, D. (2007). How leaders influence employees' innovative behavior. European Journal of Innovation Management, 10 (1), 41-64

Katz, D., Kahn, R.L. (1978). The social psychology of organizations. Administration Science Quarterly, 46, 118

Katz, D., Kahn, R.L. (1978). The social psychology of organizations. Administration Science Quarterly, 46, 118. 
Kehinde, O.A., \& Banjo, H.A. (2014). A test of the impact of leadership styles on employee performance: A study of department of petroleum resources. International Journal of Management Sciences, 2(3), 149-160.

Korman, A. K. (1966). "Consideration", "initiating structure", and organizational criteria - a review'. Personnel Psychology, 19, 349-61.

Lopez-Dominguez, M., Enache, M., Sallan, J., \& Simo, P. (2014). Transformational leadership as an antecedent of change oriented organizational citizenship behavior, Journal of Business Research, 66 (10), 2147-2152.

Mahdinezhad, M., \& Suandi, B. (2013). Transformational, Transactional Leadership Styles and Job Performance of Academic Leaders. International Education Studies, 6(11), 29-34.

MacKenzie, S. B., Podsakoff, P. M., \& Rich, G. A. (2001). Transformational and transactional leadership and salesperson performance. Journal of the academy of Marketing Science, 29(2), 115.

Masa'deh, R. , Maqableh, M. and Karajeh, H. (2014), “A theoretical perspective on the relationship between leadership development, knowledge management capability, and firm performance", Asian Social Science, 10 (6), 128-137

McColl-Kennedy, J. R., \& Anderson, R. D. (2002). Impact of leadership style and emotions on subordinate performance. The Leadership Quarterly, 13(5), 545-559.

Mullins, L.J. (2007). Management and Organisational Behaviour. (8th ed). London: Financial Times/Prentice-Hall

Northouse, P.G. (2007). Leadership: Theory and Practice. (4th ed). Thousand Oaks, CA: Sage Publications.

Obiwuru, T.C. , Okwu, A.T. , Akpa, V.O. and Nwankwere, I.A. (2011), "Effects of leadership style on organizational performance: a survey of selected small scale enterprises in Ikosi-Ketu Council development area of Lagos State, Nigeria", Australian Journal of Business and Management Research, 1(7), 100-111.

Paracha, M.U., Qamar, A., Mirza, A., Inam-ul-Hassan., \& Waqas, H. (2012). Impact of Leadership Style (Transformational \& Transactional Leadership) on Employee Performance \& Mediating Role of Job Satisfaction: Study of Private School (Educator) In Pakistan. Global Journal of Management and Business Research, 12(4), 54-64 
Pradeep, D. D., \& Prabhu, N. R. V. (2011). The relationship between effective leadership and employee performance. Journal of Advancements in Information Technology, 20, 198-207.

Rouche, J.E., Baker, G.A., \& Rose, R.R. (1989). Shared vision: Transformational leadership in American community colleges. Washington: Community College Press.

Sani, A., \& Maharani, V. (2012). The impact of transformational leadership and organizational commitment on job performance with the among lecturers of faculty in the Islamic Maulana Malik Ibrahim Malang university the mediating effects of organisational citizenship behavior. International Journal of Academic Research, 4 (4), 102-106

Spangler, W. D., \& Braiotta Jr, L. (1990). Leadership and corporate audit committee effectiveness. Group \& Organization Studies, 15(2), 134-157.

Sparkling, A. E., Mollaoglu, S., \& Kirca, A. (2016). Research synthesis connecting trends in architecture, engineering, and construction project partnering. Journal of Management in Engineering, 33(1), 04016033.

Suharto dan Cahyo (2005). Pengaruh Budaya Organisasi, Kepemimpinan dan Motivasi Terhadap Kinerja Sumber Daya Manusia Di Sekretariat DPRDPropinsi Jawa Tengah. JRBI, 1(1), 13-30.

Sundi, K. (2013). Effect of Transformational Leadership and Transactional Leadership on Employee Performance of Konawe Education Department at Southeast Sulawesi Province. International Journal of Business and Management Invention, 2(12), 50-58 Doi:www.ijbmi.org

Thamrin, H. M. (2012). The influence of transformational leadership and organizational commitment on job satisfaction and employee performance. International Journal of Innovation, Management and Technology, 3(5), 566572.

Tsigu, G. T., \& Rao, D. P. (2015). Leadership styles: their impact on job outcomes in Ethiopian banking industry. ZENITH International Journal of Business Economics \& Management Research, 5(2), 41-52.

Vinger, G. (2009). The restructuring of a university: a call for the exhibition of transformational leadership behaviours. The International Journal of Learning, 16(10), 267-286 
Wang, G., Oh, I., Courtright, S. H., Amy E. \& Colbert, A. E. (2011). Transformational leadership and performance across criteria and levels: A meta-analytic review of 25 years of research. Group \& Organization Management, 36(2) 223-270. doi: 10.1177/1059601111401017

Welbourne, T. M., Johnson, D. E., \& Erez, A. (1998). The role-based performance scale: validity analysis of a theory-based measure. Academy of Management Journal, 41(5), 540-555.

Yammarino, F. J., \& Dubinsky, A. J. (1994). Transformational leadership theory: Using levels of analysis to determine boundary conditions. Personnel psychology, 47(4), 787-811. 